ISSN 2658-4824

УДК 792.01

DOI: 10.33779/2658-4824.2019.1.167-175

\section{А.С. САГИТОВА}

Уфимский государственный институт искусств имени Загира Исмагилова

2. Уфа, Россия

ORCID: 0000-0003-0466-9433

aiselu83@mail.ru

\author{
AISYLU S. SAGITOVA \\ Ufa State Institute of Arts \\ named after Zagir Ismagilov \\ Ufa, Russia \\ ORCID: 0000-0003-0466-9433 \\ aiselu83@mail.ru
}

\section{Мировоззренческие истоки башкирского театра}

Искусство башкирского народа, как и искусство всех народов мира, зародилось в глубокой древности и имеет свои уникальные корни, которые уводят нас в те далёкие времена, когда башкиры поклонялись языческим богам и вся их жизнь была служением природным стихиям. Это времена, когда был создан великий эпос «Урал-батыр», во многом обусловивший мировоззрение и мировосприятие башкирского народа на многие века. Именно в эпическом характере этого произведения и в его чистой, непосредственной незамутнённой, пафосности кроется разгадка романтически-приподнятого башкирского исполнительского искусства. Зачастую даже сегодня, в техногенный век всепроникающей расчётливости, холодной рациональности и безграничной иронии, в национальном театре в некоторых спектаклях сохраняется особый стиль произношения текста эпического распевания. В любой постановке Башкирского государственного академического театра драмы имени Мажита Гафури - будь то национальная, русская или западноевропейская классика, актуальная современная драматургия в ней всегда звучит необычная, характерная только для башкирского языка, своеобразная возвышенная, мелодическая, поэтическая интонация речи. Эта своеобразная интонация есть неотъемлемая часть (древняя, мифологическая, архетипическая) башкирского сознания и его продукта башкирского языка, по звучанию и мелодике напоминающего героические песнопения: строгие, размеренные, несуетливые, может быть, иногда суровые и одновременно

\section{The Worldview Sources of Bashkir Theater}

The art of the Bashkir people, similarly to the art of all the peoples of the world, emerged in very early historical times and has its unique roots, which lead us into those remote times when the Bashkirs worshiped pagan gods, and all of their life was that of service to natural elements. These were the times when the great epos "Ural-batyr" was created, which in many ways has conditioned the worldview and world-perception of the Bashkir people during the course of many centuries. Particularly in the epic character of this work and in its pure, unadulterated, direct pathos lies the key to the romantically elevated Bashkir performing art. Frequently even presently, in the technological age of all-pervading mercenary self-interest, cold rationality and unlimited irony in national theater, in some performances a special style of pronunciation of the text as a type of epic singing is preserved. In any of the productions carried out by the Bashkir State Mazhit Gafuri Academic Theater of Drama - whether it be national, Russian or Western European classics or relevant contemporary dramaturgy it always has the sound of the unusual, original, elevated, melodic, poetical intonation of speech, characteristic only to the Bashkir language. This peculiar intonation is an integral part (ancient, mythological, and archetypical) of the Bashkir consciousness and its product - the Bashkir language, in its sound and melody reminding heroic chants: strict, measured, not restless, maybe, at times harsh and at the same time soft. The language is an invaluable repository 
мягкие. Язык является бесценным хранилищем древней культуры и истории людей. Театральное исполнительское искусство башкир, стремящееся к объёмным, рельефным формам, притчевым, глубинным сюжетообразующим смыслам и эпической распевности, во многом определяется именно его мифологическим мироощущением. Последнее генетически присуще башкирскому народу и воспринимается им как «подлинная и максимально конкретная реальность». Мировоззренческие истоки, фольклорные традиции позволяют башкирскому театру сохранять своё лицо и, идя в ногу со временем, ориентироваться на фольклорные традиции как меру вещей и точку отсчёта в современном, стремительно меняющемся мире. В этом заключается уникальный смысл движения и развития башкирского театра: быть со-временным (со временем), но основываться на непреходящем и вечном.

\section{Ключевые слова:}

башкирский театр, фольклор, национальные традиции, миф, обряды, ритуал, актёр, режиссёр, спектакль. of people's ancient culture and history. The Bashkir art of theatrical performance, which aspires towards capacious relief forms, parabolic, profound plot-generating meanings and epic melodiousness, is in many ways determined particularly by its mythological world perception. The latter is genetically intrinsic to the Bashkir people and is perceived by them as "a genuine and maximally concrete reality”. The worldview sources and folklore traditions make it possible for the Bashkir people to preserve their face and, keeping up with the time, to orient themselves on folklore traditions as the measure of things and the reference point in the constantly changing contemporary world. Therein is contained the unique sense of motion and development of the Bashkir theater: to be con-temporary (in tune with the times), but to base itself on the timeless and the eternal.

\section{Keywords:}

the Bashkir Theater, folklore, national traditions, myth, rituals, actor, Producer, performance.

Для цитирования/For citation:

Сагитова А.С. Мировоззренческие истоки башкирского театра // ИКОНИ. 2019. № 1. C. 167-175. DOI: 10.33779/2658-4824.2019.1.167-175.

Л ев Николаевич Толстой, который любил отдыхать в башкирских степях на кумысолечении, в 1871 году писал жене Софье Андреевне: «Ново и интересно многое: и башкиры, от которых Геродотом пахнет...» (цит. по: [5, с. 10]). Представляется, что в этом и заключается ключ к пониманию всей культуры башкирского народа. Иначе как объяснить тот факт, что национальной сцене всегда были близки трагедии в первую очередь древнегреческих авторов Софокла и Еврипида, неоднократно ставившиеся в Башкирском театре со дня его основания и в течение целого столетия. Или, например, трагедии Шекспира, которого башкирский зри- тель тоже всегда считал «своим» драматургом за его страстный темперамент и трагические конфликты. Начиная с самых первых дней создания театра, образы Эдипа, Отелло, Медеи, Макбета были излюбленными ролями в репертуаре не одного поколения башкирских актёров. В вершинных достижениях национальной драматургии, особенно в трагедиях Мустая Карима «Не бросай огонь, Прометей!» и «В ночь лунного затмения», также слышатся отголоски древних пракультур. Не потому, что в этих произведениях речь идёт о делах «минувших дней», а потому что в них заложен код к пониманию национального самосознания и его этнопсихологии. 
Мифическое сознание - это жизненное отношение к окружающему миру. А «Урал-батыр - это человек, который обессмертил природу, слился с ней и стал её олицетворением. Урал - это мир, окружающий людей, ибо слово „урал“ образовано от слова „ура“- „окружай“. Следовательно, люди свято верили, что окружающий их мир и природу, которую они обозначили словом „урал“, сотворил батыр Урал» [1, с. 190]. Поэтому у башкир такое священное отношение к природе, к земле, к солнцу, к каждому дереву.

Известный арабский путешественник Ахмед ибн-Фадлан, посетивший башкирские земли в 922 году, писал, что башкиры верили 12 богам, которые управляли временами года, а также дождём, ветром, людьми, жизнью и смертью. Мировоззрение древних башкир во многом определилось и тотемистическими взглядами и космогоническим представлением, а также антропоморфизмом: солнце (кояш) - это девушка, а луна (ай) — джигит. Вспомним имеющую множество вариаций известную башкирскую сказку о том, как шедшая за водой девушка залюбовалась месяцем-юношей и сказала, что если бы у неё был муж такой же красивый, как месяц, она непременно родила бы ему богатыря. И месяц взял девушку себе в жёны, и теперь она стоит там с коромыслом и вёдрами [10, с. 266]. Другая версия - девушка-сирота посетовала на свою тяжкую судьбу, пожаловалась, что мачеха заставляет её ходить за водой ночью, и луна, пожалев бедняжку, забрала её к себе. Поэтому в полнолуние, согласно мифу, можно увидеть на лунном диске девушку с коромыслом на плечах, и зовут её Зухра.

В книге С.И. Руденко «Башкиры» даётся ещё один замечательный пример, где солнце в башкирской мифологии фигурирует под видом «красной водяной девы» (ьыуьылыу). Её длинные, в несколько саженей, волосы плавают на водной глади. Сильные и могучие батыры, видя выплывающую из воды диву, изумляются её красоте, а один из них самый сильный и ловкий - хватается за длинные пряди и опускается в водное царство, где отец водяной девы выдаёт её за него замуж [там же, с. 266]. Затем он отправляет их обоих на землю, на родину батыра, с бесчисленными стадами скота, который впоследствии приносит большое потомство.

Помимо одухотворения природных явлений, башкиры были абсолютно уверены в существовании всевозможных ду́хов. Они полагали, что каждое урочище, каждое сколько-нибудь приметное место имеет хозяина (эйә), отсюда - хозяин горы (тау эйәһе), хозяин пещеры (мәмерйә эйәһе), водяной (Һыу эйәһе), домовой (өй эйәһе) [там же, с. 268]. Последний, по мнению башкир, имелся в каждом доме. И если его не сердили, то зла он никому не делал. Поэтому, заходя даже в пустой дом, башкиры всегда громко здоровались, как бы приветствуя невидимого хозяина. За этим, отчасти, кроется и хорошее воспитание: поздороваться - значит проявить внимание и уважение.

Отголоски таких верований дают о себе знать и сегодня. Во многих башкирских сёлах после захода солнца не рекомендуется ходить в баню, так как в это время там якобы парится домовой, который может запарить человека до смерти. В воспоминаниях одного из первых актёров Башкирского театра драмы Гималетдина Мингажева есть по этому поводу очень трогательный ироничный рассказ о том, как он учился играть на баяне. Известно, что в начале XX века люди, занимающиеся театром, танцами, музыкой, изобразительным искусством, считались в исламской религии нечестивыми грешниками. Про них говорили «ен кағылған", то есть помечен шайтаном. И поскольку, по преданию, шайтаны собирались ночью в бане, начинающий актёр решил учиться играть на баяне именно там и именно по ночам - для того чтобы духи помогли ему виртуозно 
овладеть инструментом. Так Гималетдин Мингажев стал не только актёром, но и первым лучшим гармонистом в оркестре Башкирского театра.

Легенды и мифы древних башкир отчётливо говорят о тесной связи человека с землёй, небом, водой. Древний башкир боготворил природу, и вся его жизнь была посвящена служению ей. Неслучайно многие башкирские имена носят названия небесных светил и звёзд (Акйондоз, Кояшбай, Айьылыу, Айсыуак, Йыһаннур, Таңсулпан), гор (Урал, Ирәндек), рек (Из̧ел, һакмар, Дим), камней (Таштимер, Сынтимер, Ынйы), птиц (Һомай, Карлуғас, һандуғас, Бөркөт), животных (Арыс̧лан, һеләүцен), явлений природы (Шәфәк). Неудивительно, что многие герои и персонажи башкирской сцены носили эти имена. У башкир есть поверье, согласно которому имя ребёнка должно отражать его внутренний мир, его сущность («Баланың исеме есеменә тап килергә тейеш»). Оттого-то издревле детям давались звучные имена, чтобы заранее «запрограммировать» их характер, волю, устремления и даже судьбу. Таким образом пытались наделить детей могуществом гор и прочностью камня, яркостью звёзд и бездонностью неба, теплотой первого весеннего дождя и ароматом лунных цветов. Имена мощного звучания башкиры особенно старались дать новорождённым мальчикам в надежде, что те вырастут бесстрашными воинами, отважными защитниками своего рода, а также хранителями традиций, сказителями и сэсэнами родной земли. Эта вера подтверждает тотемистическую образность башкир, их тождество с окружающим миром. М.М. Маковский писал, что первобытный человек, воспринимая себя как внешний мир, делает всё то, что делает и этот внешний мир, то есть повторяет его жизнь, где творец и творимое отождествляются [9, с. 22]. Представляется, что и в этой традиции отчасти может заключаться разгадка к пониманию башкирского этноса.
Центральное место в башкирских эпических повествованиях отводится изображению богатырских подвигов неотъемлемой части башкирской драматургии и театра в частности. Как правило, в образе любого эпического героя воплощаются общечеловеческие нравственные черты: честность и бескорыстность, справедливость и гуманизм, неотступная целеустремлённость и неимоверная физическая сила. В повести Мустая Карима «Долгое-долгое детство», которая в Башкирском академическом театре драмы ставилась дважды (1978; 2003), есть сцена, где герой по имени Юмагул, который вот-вот должен стать отцом, плетёт аркан. На вопрос мальчика по прозвищу Кендек (то есть Пупок - что тоже несёт в себе сакральный смысл соединения человека с матерью, с землёй, с космосом), зачем ему аркан, он отвечает, что когда его сыну Хабибулле, который должен вотвот родиться, исполнится семнадцать, он вручит ему этот аркан. «А зачем аркан, когда семнадцать исполнится?» - продолжает интересоваться Кендек. И тогда Юмагул рассказывает древнее предание: «На самой вершине горы Урал растёт чёрный дремучий лес, куда человека нога не ступала. А в том лесу - круглая поляна, а на той поляне - круглое озеро. Озеро это в семьдесят обхватов, а дна и вовсе нет. И в озере том - ни рыбы, ни другой живности, один только златогривый Акбузат. Конь этот ветром веет, птицей взмывает, ожидаемое тобой приблизит, прошлое твоё вернёт, с человеком по-человечески говорит, с богом тайны делит - вот какой это конь... В самую короткую ночь, в час, когда зацветает орешник и с липы капает мёд, из озера, разрезая водную гладь, полоща в ней гриву, появляется Акбузат. Изловчишься накинуть ему на шею аркан в семьдесят обхватов длиной - твоим будет конь. Но такое дело под силу только джигиту, который днём звёзды видит, ночью на зверя идёт. Вот зачем нужен аркан!» «Неплохи же дела у Хабибуллы. Сам ещё и не вылупился, 
а его уже златогривый конь дожидается!» - с детской завистью восклицает Пупок.

В этой сказке кроется глубокий смысл: каждого человека ожидает в жизни златогривый конь. Сумеешь стать джигитом - конь твой. Сможешь стать человеком - приблизишься к божественной тайне, ведь быть человеком - это и есть великая тайна. И потому в легендарном спектакле Рифката Исрафилова 1978 года «И судьба - не судьба!» по этой повести художник Тан Еникеев наверху у самых колосников - в центре разомкнутого сценического пространства - поместил детскую колыбель, над которой как символ мечты, красоты и силы парил игрушечный Акбузат.

В башкирской мифологии образы коня (Акбузат, Тулпар) и человека не просто дополняют друг друга - они неразрывно связаны и составляют единое целое. Так, седовласый или златогривый Акбузат, по преданиям и легендам, - помощник и советчик богатырей, владелец булатного меча. Тулпар же - получеловек-полуконь - у древних башкир воплощает свободолюбивый дух народа, вдохновляющий сэсэнов, музыкантов, художников на творчество. В соответствии с преданиями, он понимает язык людей и, чувствуя их души, всегда приходит на помощь как в радостные, так и в тяжёлые моменты жизни. Этот образ стал центральным в пьесе Флорида Булякова «Встань и вознесись, мой Тулпар!», где трагические события конца 1930-х годов метафорически преломились в драме 1990 года в изображении истребления лучших пород лошадей якобы в связи с распространением язвы.

С принятием ислама, который начал проникать в Башкортостан ещё в X столетии и был усвоен только ко второй половине XIV века, пережитки старых религиозных представлений ещё долго коренились в народном сознании и передавались из поколения в поколение. кроме того, как полагают учёные, мно- гие каноны ислама несут в себе черты язычества, так как основоположник религии Мухаммед опирался главным образом на языческие обряды [6, с. 25]. До сих пор в народе живут обычаи и ритуальные действа, дошедшие до нас от далёких предков.

Одним из самых рапространённых и ярких фольклорных театрализованных действ у башкир, как и у большинства народов мира, является свадебный обряд. Башкирская свадьба - это целая культуpa, сопровождающаяся переодеваниями и ряжением, прятанием, поиском и выкупом женихом невесты, состязаниями, хождением девушек в поле с причитаниями (сеңләү). Она полна самобытных свадебных обычаев, среди которых можно выделить преподнесение калыма кобылы, овцы или коровы - как залога счастья и благополучия новобрачных, причём невеста должна была обязательно опереться на скотину. Известны также бросание серебряных монет в принесённое невестой ведро с водой, осыпание её этими монетами с ног до головы. Девушка должна была наступить на подушку перед домом свекрови, чтобы жизнь была такой же мягкой... Присутствующие на свадьбе - это не пассивные зрители, а её участники, вполне определённые персонажи с отведёнными ролями, словами, действиями [13, с. 16]. Этот ритуал - готовый сценический праздник для национального зрителя. Один из самых первых башкирских драматургов Мухаметша Бурангулов, зная культуру и традиции своего народа, написал пьесу, которая так и называется - «Башкирская свадьба», где в мельчайших подробностях воссоздаётся древний ритуал бракосочетания. Эта пьеса много раз ставилась на сцене национального театра, и сегодня она является знаковым драматургическим произведением в его истории.

Традиционная башкирская свадьба делится на три основных эпизода предсвадебный, собственно свадебный и послесвадебный. Каждый из них пред- 
ставляет собой сложный комплекс ритуалов и поэзии [там же, с. 33-34]. Так, надкусывание уха ещё в детском возрасте в башкирском магическом обряде «свадьба серьги» (Һырға-алка туй) играло более значительную роль, нежели само свадебное торжетсво. Девушка с меткой (мнимой) на ухе могла принадлежать только тому, кто ей надкусил его в детстве. В спектакле Башкирского академического театра "Ахметзаки Валиди туган» Нажиба Асанбаева в постановке Айрата Абушахманова (2010) этот эпизод «свадьбы серьги» гармонично и этнографически точно вошёл в сложную структуру сценического повествования. Ритуал сопровождался песнями, приговорами (әйтем), своеобразной обрядовой хореографией и благопожеланиями самобытными реликтами, отображающими народную педагогику и философские воззрения в поэтической форме. Надо отметить, что в последнее время использование ритуальных обрядов заметно обогатило сценическую культуру Башкирского театра. Так, в спектакле по повести Мажита Гафури «Черноликие» (режиссёр - Айрат Абушахманов, 2014), ставшем обладателем Всероссийской национальной премии-фестиваля «Золотая маска» в номинации «Лучшая работа художника по костюму» (Альберт Нестеров), обряды, обычаи и традиции обрели новую жизнь. Эта постановка стала ещё одним доказательством того, что национальные традиции не сдерживают развитие театра, а, напротив, стимулируют к новым поискам, помогают ему осмысливать сегодняшнее состояние общества через призму древних ритуалов.

По-башкирски свадьба называется «туй». Однако в сознании башкир слово «туй» имеет более широкое понятие: это праздник как таковой, и посвящён он бывает не только бракосочетанию молодых людей, но и смене времён года, природным явлениям. Чтобы ещё раз убедиться в том, что башкирский народ всегда жил в гармонии с природой и являлся её необъемлемой частью, достаточно вспомнить весенний праздник Карғатуй, летний - Кәкүк туйы, или Кәкүк сәйе, и отмечаемый в сезон охоты Айыутуйы.

Башкиры говорят: у человека бывает три свадьбы - рождение, вступление в брак и смерть. То есть туй - это переход человека из одного мира в иной, из одной половозрастной группы в другую, момент инициации. Смерть - это тоже «свадьба», и ритуал прощания с усопшим у башкир также носит поэтический характер. В обрядовом плаче и причитаниях, которые служили средством освобождения от тяжелых мыслей, горя и выполняли очистительную, катарсическую функцию, есть элементы театра. Как отмечает учёный-исследователь, сэсэния (исполнительница кубаиров) P.А. Султангареева, башкирские причеты по усопшему построены в форме диалога между живым и мёртвым [там же, с. 29]. Через усопшего живые в экстатической форме (Һеүләү) обращались к Небесам и Тэнгри с просьбой о дожде, счастье, благополучии, здоровье и т. д. Ислам, запрещающий громко плакать и горевать, внёс существенные изменения в причеты и вытеснил ритуальные песнопения. Ритуальный плач заменяется религиозными напевными чтениями, баитами, мунаджатами, но манера исполнения и идейное содержание, по сути, остаются неизменными [там же, с. 31].

В постановках Башкирского театра ритуал смерти всегда решался по-разному: где-то излишне высокопарно и неправдиво, где-то психологически точно, гдето метафорически красиво и условно, а где-то - слышался настоящий «сухой голос трагедии». Одной из самых знаковых таких сцен в истории Башкирского драматического является эпизод ухода в иной мир Старшей Матери в спектакле «И судьба - не судьба!» Рифката Исрафилова (1978). Этот образ в исполнении легендарной Зайтуны Бикбулатовой, народной артистки СССР, символизировал в спектакле тот «мост», который объеди- 
няет два берега - небытие и вечность. Мудрая, нравственно-одухотворенная, с драматической судьбой неразделённой любви, мягкая и в то же время строгая, добрая, но с достоинством, Старшая Мать - повитуха по своему предназначению. Принимая человека в этот мир, она относится к своему делу как к святому долгу, и поэтому, оказавшись на пороге вечности, она просит прийти к ней каждого, кого приняла в родах, чтобы дать им своё Фатиха - Благословение.

Вот она лежит на больших качелях, которые медленно раскачиваются в такт музыке. Вокруг неё собрались «её» дети. Каждого она помнит и каждого любит, как собственного ребёнка, но своих детей у неё не было. Она говорит, что собирается в дальний путь и просит всех не плакать - ведь так положено, что каждому когда-то предстоит оставить этот мир и уйти в вечность... Она спокойно и с достоинством прощается с каждым. И лишь одного из них - Шагидуллу, который посмел поднять руку на родную мать, — она не может благословить. «Бить человека, подарившего тебе жизнь, — величайший из грехов, - говорит Старшая Мать. Делайте друг другу добро - таково моё вам благословение». С этими словами Старшая Мать исчезает в глубине сцены, оставляя за собой белый шлейф - «мост» в иной мир, куда дети, по обычаю, бросают горсти чёрной земли.

Таким образом, идея доброты и мира на земле - главный мотив, заданный в эпосе «Урал-батыр», - проходит через всё художественное творчество башкирского искусства и является основополагающей, смыслообразующей частью духовного мира башкир.

Важную роль в эстетическом воспитании народа на протяжении многих веков играло творчество сэсэнов, исполнительское мастерство которых можно было бы сопоставить либо с театром одного актёра (когда один сэсэн исполнял кубаиры, эпос, песни, а народ слушал), либо театра вообще (когда на йыйынах происходило состязание нескольких сэсэнов). Иногда эти соревнования ума и смекалки становились решающими в настоящих кровавых битвах, как это произошло в одном из шедевров устного народного творчества - состязании в айтышах (әйтеш) сэсэнов Акмырзы и Кубагуша.

Сэсэн - поэт-импровизатор, философ и учитель, неординарная личность. Он обладал феноменальной памятью, хорошими голосовыми данными и художественным даром. Сэсэны исполняли свои произведения речитативом, нередко в сопровождении народных музыкальных инструментов. Слово сэсэна всегда было весомым и важным. В самые трудные минуты жизни за советом шли к сэсэну, аксакалу, который в поэтической форме давал ответы на волнующие людей вопросы, направлял и вдохновлял их. Сэсэнизм - одна из важных ветвей в формировании башкирского театра, оставившая неизгладимый след в характере и манере его исполнительского искусства, требущего сегодня глубокого изучения и научного исследования.

Башкирские легенды, предания, сказки, ритуалы, обряды легли в основу зарождающейся национальной драматургии в начале XX века и стали тем фундаментом, на котором в дальнейшем сформируется уникальное, самобытное башкирское профессиональное театральное искусство. "Мактымьылыу», «Буранбай», «Карағол» Дауыта Юлтыя, «Ынйыкай менән Юлдыкай» Хабибуллы Габитова, «Ашказ̧ар», «Шәурәкәй», «Ялан йәркәй», «Башкорт туйы» Мухаметши Бурангулова - первые пьесы, по которым в Башкирском театре были поставлены первые спектакли. Именно на них складывались отличительные черты и специфика режиссёрских постановочных методов, а первые башкирские актёры вырабатывали и оттачивали особенности национального исполнительского искусства.

К открытию первого в республике драматического театра, ныне Башкирского 
государственного академического театра драмы имени Мажита Гафури, в 1919 году Валиулла Муртазин-Иманский подошёл со своей программой, отдельные принципы которой легли в основу традиций исполнительского искусства национальной сцены. Одним из принципов являлась опора на башкирский фольклор. Исследователь С.Г. Кусимова отмечает, что «ориентируясь на известные ему [Муртазину-Иманскому] формы европейского театра, синтезируя опыт современной русской и татарской сцены, В. МуртазинИманский активно внедрял в сценическую практику традиции богатейшего башкирского фольклора и народного музыкально-поэтического исполнительства» [7, с. 7]. По мнению С.С. Саитова, Муртазин-Иманский создавал спектакли - массовые праздники, спектакли священные обряды, спектакли - народные собрания [12, с. 29]. В этих постановках театр обращался к национальной истории, мифу, легенде, народной песне в жанре узун-кюй - долгой и длинной напевной песне, главный герой которой - носитель любви к своему народу и исполнитель долга перед родной землёй.

В течение целого столетия башкирский фольклор не раз становился благодатной почвой для художественных поисков национальной сцены. Иногда этот богатый духовный материал использовался театром как иллюстративный, этнографический экскурс в древность, а зачастую являлся предметом постижения бытия. Во многих спектаклях с помощью национального сюжета театр выходил к проблемам общечеловеческого звучания, удивлял зрителя новыми режиссёрскими решениями, необычными и увлекательными актёрским работами. И сегодня театр продолжает оставаться преданным своим корням. Но при этом он по-прежнему открыт и для ультрасовременных экспериментов, и для новых способов отражения действительности.

\section{थ литЕРАТУРА $\sim$}

1. Абдуллин А.Р. Культура и символ. Уфа: Гилем, 1999. 217 с.

2. Башкирия в русской литературе. В 5 томах. Т. II. Уфа: Башкортостан, 1964. 468 с.

3. Башкирский государственный академический театр драмы имени Мажита Гафури. История и современность в спектаклях и лицах. Страницы истории / сост. С.Г. Кусимова. Уфа, 2014. 206 с.

4. Башкирский государственный академический театр драмы имени Мажита Гафури. История и современность: фотохроника / сост. Г.Я. Магадеева, Р.К. Ягудина, А.А. Балгазина. Уфа, ООО «Информреклама», 2014. 124 с.

5. Башкирский государственный академический театр драмы имени Мажита Гафури. Спектакли, актёры, роли / сост. С.Г. Кусимова. Уфа, ООО «Информреклама», 2014. 108 с.

6. Кузбеков Ф.Т. История культуры башкир. Уфа: Китап, 1997. 128 с.

7. Кусимова С. Путь театра. Уфа: Государственное республиканское издательство «Башкортостан», 2004. 146 с.

8. Лосев А.Ф. Диалектика мифа. М.: Мысль, 2001. 558 с.

9. Маковский М.М. Сравнительный словарь мифологической символики в индоевропейских языках: Образ мира и миры образов. М.: Гуманит. изд. Центр ВЛАДОС, 1996. 416 с.

10. Руденко С.И. Башкиры: Историко-этнографические очерки. Уфа: Китап, 2006. 376 с.

11. Рукописи инсценировки Р.В. Исрафилова по повести Мустая Карима «Долгое-долгое детство» (архив музея БГАТД им. М. Гафури).

12. Саитов С. Строитель башкирского театра // Рампа. 2009. № 11. С. $28-29$.

13. Султангареева Р.А. Башкирский свадебно-обрядовый фольклор / УНЦ РАН. Уфа, 1994. $191 \mathrm{c}$. 
Об авторе:

Сагитова Айсылу Сынтимировна, кандидат искусствоведения, доцент кафедры истории и теории искусства, Уфимский государственный институт искусств имени Загира Исмагилова (450008, г. Уфа, Россия), ORCID: 0000-0003-0466-9433, aiselu83@mail.ru

\section{er REFERENCES}

1. Abdullin A.R. Kul'tura i simvol [Culture and Symbol]. Ufa: Gilem. 1999. 217 p.

2. Bashkiriya v russkoy literature [Bashkiria in Russian Literature]. In 5 volumes. Vol. II. Ufa: Bashkortostan, 1964. 468 p.

3. Bashkirskiy gosudarstvennyy akademicheskiy teatr dramy imeni Mazhita Gafuri. Istoriya i sovremennost' $v$ spektaklyakh i litsakh. Stranitsy istorii [Bashkir State Academic Drama Theater named after Mazhit Gafuri. History and Modernity in Performances and Faces. Pages of History]. Comp. S.G. Kusimova. Ufa, 2014. 206 p.

4. Bashkirskiy gosudarstvennyy akademicheskiy teatr dramy imeni Mazhita Gafuri. Istoriya i sovremennost': fotokhronika [Bashkir State Academic Drama Theater named after Mazhit Gafuri. History and Modernity: Photo Chronicle]. Comp. G.Ya. Magadeeva, R.K. Yagudin, A.A. Balgazina. Ufa, 2014. $124 \mathrm{p}$.

5. Bashkirskiy gosudarstvennyy akademicheskiy teatr dramy imeni Mazhita Gafuri. Spektakli, acteri, roli [Bashkir State Academic Drama Theater named after Mazhit Gafuri. Performances, Actors, Roles]. Comp. S.G. Kusimova. Ufa, 2014. 108 p.

6. Kuzbekov F.T. Istoriya kul'turi bashkir [The History of Culture of the Bashkirs]. Ufa: Kitap, 1997. $128 \mathrm{p}$.

7. Kusimova S.G. Put' teatra [Path of the Theater]. Ufa: Bashkortostan, 2004. 146 p.

8. Losev A.F. Dialektika mifa [The Dialectic of Myth]. Moscow: Mysl, 2001. 558 p.

9. Makovsky M.M. Sravnitel'nyy slovar' mifologicheskoy simvoliki $v$ indoevropeyskikh yazikakh: Obraz mira i miry obrazov [Comparative Dictionary of Mythological Symbols in Indo-European Languages: The Image of the World and the Worlds of Images]. Moscow: Center VLADOS, 1996. $416 \mathrm{p}$.

10. Rudenko S.I. Bashkiry: Istoriko-etnographicheskie ocherki [Bashkirs: Historical and Ethnographic Essays]. Ufa: Kitap, 2006. 379 p.

11. Rukopisi instsenirovki R.V. Israfilova po povesti Mustaya Karima «Dolgoe-dolgoe detstvo» (arkhiv muzeya BGADT imeni M. Gafuri) [Manuscripts of the Staging of R.V. Israfilov based on the Story by Mustai Karim "Long-Long Childhood" (Archive of the Museum of the Bashkir State Academic Drama Theater named after Mazhit Gafuri)].

12. Saitov S. Stroitel' bashkirskogo teatra [The Builder of the Bashkir Theater]. Rampa [Ramp]. 2009. №11, pp. 28-29.

13. Sultangareeva R.A. Bashkirskiy svadebno-obryadovyy fol'klor [Bashkir Wedding and Ceremonial Folklore]. Ufa: Ufa Scientific Center of the Russian Academy of Sciences, 1994. $191 \mathrm{p}$.

About the author:

Aisylu S. Sagitova, Ph.D. (Arts), Associate Professor at the Department of History and Theory of Art, Ufa State Institute of Arts named after Zagir Ismagilov (450008, Ufa, Russia),

ORCID: 0000-0003-0466-9433, aiselu83@mail.ru 